\title{
A LAWYER'S VIEW OF ADMINISTRATIVE PROCEDURE-THE AMERICAN BAR ASSOCIATION PROGRAM
}

\author{
ROBERT M. BENJAMIN*
}

In lectures delivered three years ago at the University of Virginia Law School, and published a year later by the Virginia Law Review Association, Judge Prettyman said: "The function of an administrative agency is the administration of law-no more, no less."1 Mr. Justice Frankfurter, in a foreword to the published volume, commented: ". . . Judge Prettyman's emphasis that the function of administrative agencies is the administration of law is more than wholesome, it is essential."2

The interest of the bar that this field of law be administered well is but part of the bar's interest that all law be administered well; but growth and change in the range and character of administrative regulation and other administrative action have presented a special challenge to the lawyer's trained capacity for dealing imaginatively with questions of procedure. Procedures, differing as they should in different fields, are still the essential framework of the administration of law in any field.

Since the administration of law by agencies takes place in the context of government, there are special considerations. I may be permitted to quote from an official report that I submitted nearly two decades ago to the Governor of New York after studying for three years the adjudicating and rulemaking procedures of New York State administrative agencies and the New York system of judicial review: ${ }^{8}$

Put in its most general terms, the problem with which this report is concerned is the problem of reconciling, in the field of administrative action, democratic safeguards and standards of fair play with the effective conduct of government. To state the problem in these terms is not to say that the elements to be reconciled are essentially opposite and

* A.B. I917, LL.B. I922, Harvard University. Law secretary, Mr. Justice Holmes, 1922-23. Member of the New York bar; Chairman, American Bar Association Special Committee on Code of Administrative Procedure; Member, American Bar Association Special Committee on Legal Services and Procedure; participant in in-service training courses in administrative law and member of panel on oral examinations for hearing officer positions, New York State Department of Civil Service. Formerly Member, Alien Enemy Hearing Boards, United States Department of Justice; Chairman, Regents' Committee on Discipline (review of disciplinary proceedings of licensed professions), New York State Education Department; Consultant, Committee on Uniform Rules, President's Conference on Administrative Procedure; Chairman, American Bar Association Section of Administrative Law; Chairman, Committees on Administrative Law, New York State Bar Association, Association of the Bar of the City of New York, New York County Lawyers' Association; Consultant on Administrative Law, Indian Law Institute, New Delhi. Author, Administrative Adjudication in the State of New Yorx (I942). Contributor to legal periodicals.

${ }^{2}$ E. Barretr Prettyman, Trial by Agency to (1959). As used by Judge Prettyman, and as used in this paper, "administrative agency" includes executive departments as well as the so-called "independent agencies."

Id. at xi.

3 Robert M. Benjamin, Administrative Adjudication in the State of New York 9 (I942) [hereinafter cited as BENJAMIN; references here and below are to the first, unnumbered, volume]. 
conflicting. On the contrary, each of them should contribute to the fulfilment of the other. Government effective in accomplishing the purposes of a democratic society is itself a safeguard of the democratic tradition, if not indeed a condition of its survival. The safeguards and standards of fair play can themselves contribute in great measure to the effectiveness of democratic government.

Elaborating the last sentence, my report said further $:^{4}$

Not only the attitude and conduct of the administrator but the form of the procedures themselves should be directed to making the person dealt with feel that he is being fairly dealt with. There is more involved here than the simple desirability that this should be so. To a considerable degree, the successful operation of any procedure requires cooperative effort by all the parties. Procedure fair on its face will go far to enlist such cooperation.

This, I am sure, states a basic attitude of the bar towards the problems of administrative procedure. And in this the bar is not alone. In 1957, the Committee on Administrative Tribunals and Enquiries appointed by the Lord High Chancellor of Great Britain, known (from the name of its chairman, Sir Oliver Franks) as the Franks Committee, submitted its report." This was "not primarily a legal committee"; ${ }^{6}$ Sir Oliver Franks, chairman of one of the largest British banks, had taught philosophy at Oxford and elsewhere and had been Provost of Queen's College, Oxford, and Ambassador to the United States, and a majority of the members of the Committee were not lawyers. The Franks Committee, with a felicity of expression we must envy, wrote: ${ }^{7}$

21. . . Administration must not only be efficient in the sense that the objectives of policy are securely attained without delay. It must also satisfy the general body of citizens that it is proceeding with reasonable regard to the balance between the public interest which it promotes and the private interest which it disturbs. ...

22. . . . In this country government rests fundamentally upon the consent of the governed. The general acceptability of these adjudications is one of the vital elements in sustaining that consent.

One aspect of these views may be summarized in a sentence: The public interest, with which administrative agencies are charged, includes an interest in procedures fair to those whom they affect. And there is more to this than "sustaining" the "consent of the governed." Fair procedures will give opportunity to those whom they affect to have their views adequately heard and considered, and to be informed of and to have opportunity to controvert opposing views. Such procedures will advance the obvious public interest that administrative action be informed and considered.

'Id. at 12.

Committee on Administrative Tribunals and Enquiries, Report, CMND. No. 218 (1957) [hereinafter cited as CMnd. No. 218].

'Wade, Recent Trends in the Administrative Process in England, 13 AD. L. Rev. 27 (1960) [the Administrative Law Review, published by the Section of Administrative Law of the ABA, was, until vol. I3, entitled Administrative Law Bulletin].

${ }^{7}$ CMnD. No. 2r8, at 5. 
It was on this concept of the public interest that the bar played the predominant part it did in the enactment of the Administrative Procedure Act of $1946,{ }^{8}$ and on this concept that it has engaged since in the activities looking towards further improvement that I discuss below. This being its guiding principle, the bar is discouraged by finding occasionally attributed to its activity in this field motives of self-interest or of the narrow interest of its clients, with a suggestion that lawyers "have a vocational stake in the formalization and elaboration of procedure before regulatory agencies, because such procedure places a premium upon the services which lawyers are trained and equipped to provide."

Such depreciation of the bar's motives is better answered than ignored. I may testify first from experience. I have worked closely for over a decade with those in the American Bar Association principally concerned with its program for the improvement of administrative procedure, and I have found among my colleagues no narrow or self-interested motive. But I need not rely on such testimony. The support of the bar for shortening and simplifying hearing proceedings through the development of pretrial conference techniques and the extension of pretrial procedures in federal agencies ${ }^{10}$ is one short and concrete answer. I take another instance from my New York experience:

Following a recommendation in my 1942 report to the Governor of New York, the New York State Bar Association and the Association of the Bar of the City of New York achieved the amendment of article six, section seven, of the New York Constitution (in 1951) and of section 589 of the New York Civil Practice Act (in 1952) to permit the Court of Appeals (our highest court) to grant leave to appeal from non-final orders of the Appellate Divisions in proceedings instituted by or against administrative agencies. This reform, carried through by bar associations, was motivated wholly by the interest of administrative agencies in solving a problem of theirs summarized thus in a report of the Committee on Administrative Law of the Association of the Bar: $:^{12}$

Under existing law, when the Appellate Division reverses a determination of an administrative agency and by a non-final order remits the matter to the agency for further proceedings, the agency must (except in the limited instances referred to in the next paragraph) either acquiesce in the Appellate Division's determination or ask the Appellate Division for leave to appeal on certified questions; its power to appeal thus depending upon

860 Stat. 237,5 U.S.C. $\$ \S$ I00I-II (1958).

'Heady, The New Reform Movement in Regulatory Administration, 19 PuB. AdMrn. Rev. 89, 99 (1959).

${ }_{10}$ See, e.g., Comm. on Improvement of Administrative Procedures, Report, 4 AD. L. BuLl. I2I, 123 (1952); Agenda of Annual Meeting, 5 id. at 65 (1953); Comm. on Improvement of Administrative Procedures, Report, id. at ro8.

11 BENJAMIN 366-68.

12 The Committee's report is unpublished; it was approved by action of the Association in December 1949. Jurisdiction of Court of Appeals on Appeals from Non-Final Orders in Proceedings Involving Administrative Agencies, Ass'N of THE BAR of THE CrTy of NEW YoRK YB. 284 (1950). See also Comm. on Administrative Law, Report, 73 N.Y.S.B.A. Rep. 315, 316 (r950); Comm. on Administrative Law, Report, 75 id. at 349 (I952). 
the action of the court which has rendered a determination adverse to the agency's contentions.

-...

Unless leave to appeal is granted by the Appellate Division on certified questions or unless the agency is willing and able to file a stipulation for final order absolute, the agency is thus obliged to comply with the determination of the Appellate Division, even though it may involve important and novel questions of law, including questions of administrative procedure. Once having complied, the agency can no longer appeal from what would then be its own determination.

There could be no clearer instance of bar association action motivated solely by the public interest, without any possibility of private advantage.

The bar's concern with this misconception of its motive is more than a matter of pride. Doubt that the bar is motivated by the public interest may impede a meeting of minds with those of other disciplines in dealing with particular proposals.

The bar does not question the motives of those with whom it may find itself in disagreement. We do, however, find not infrequently that suggestions for procedural change elicit from administrators forecasts of difficulties which appear to us to be imaginary.

We are disturbed also by the building up of a mystique, of a personification of "the administrative process" (however that is to be defined) which enables one to characterize current differences of opinion as "the ordeal of the administrative process."13 With foresight of this development, a colleague of mine in the American Bar Association ${ }^{14}$ suggested a number of years ago that the oath of office ${ }^{15}$ be amended to read: "I do solemnly swear that I will support and defend against all enemies, foreign and domestic, the Constitution of the United States and the Administrative Process. ..."

\section{I}

The American Bar Association's Interest and Activity-Generad

I have so far spoken largely in general terms, which I believe to be applicable to lawyers generally. But of course the bar is not monolithic, and not all lawyers (and, I may add, not all lawyers in the American Bar Association) have the same judgment as to how the public interest, as I have defined it, is to be served. I was originally asked to write for this symposium on "the efforts of the organized bar." It will, I think, be most useful to deal from here on primarily with the current official program of the American Bar Association, in which I have participated from its inception. Before dealing with the current legislative program, I shall mention

\footnotetext{
${ }^{13}$ Kintner, The Current Ordeal of the Administrative Process: In Reply to Mr. Hector, 69 YalE L. J. 965 (1960).

${ }_{14}$ John $W$. Cragun, of the District of Columbia bar, my predecessor as chairman of the Section of Administrative Law and as chairman of the Special Committee on Code of Administrative Procedure, and presently vice-chairman of that committee.

${ }^{15}$ Cf. 5 U.S.C. $\$ 16$ (1958).
} 
briefly other approaches to the solution of problems of administrative procedure that have had the Association's support.

The President's Conference on Administrative Procedure, called in 1953 and working through I954, had been advocated, ${ }^{\mathbf{1 6}}$ and was strongly supported, by the American Bar Association. A former president of the Association, George Maurice Morris, served as vice-chairman of the Conference until his untimely death, and many members of the Association (in and out of the Government) were among those serving as members of the Conference or as consultants to its various committees. ${ }^{17}$ For a description of the work of the Conference, I refer to the lectures by Judge Prettyman, its chairman, from which I quoted at the beginning of this paper. ${ }^{18}$

The Association supports also the organization, momentarily expected as this paper is written, of a successor and permanent Administrative Conference of the United States. ${ }^{19}$ The details of organization of the new Conference are not yet known; but I shall have something to say about some aspects of its organization in my later discussion of the American Bar Association's legislative program for an Office of Administrative Procedure.

The American Bar Association has thus strongly supported, and in this and other ways ${ }^{20}$ has participated in, efforts primarily of the administrative agencies themselves to improve procedures.

The Association has also strongly urged constant and detailed attention by the Congress to the problems of administrative procedure. At its meeting in February 1956, the same meeting at which it adopted the resolutions basic to the Association's current legislative program, the House of Delegates of the Association adopted a resolution urging the establishment by the Congress of a permanent Committee on Administrative Procedure. ${ }^{21}$ It was, I believe, primarily due to this initiative that there was set up in the Senate Committee on the Judiciary its Subcommittee on Administrative Practice and Procedure. ${ }^{22}$ There has been activity also in the

${ }^{16}$ Proceedings of the House of Delegates, 78 A.B.A. REP. 347,359 (I953).

${ }^{17}$ I had the honor of serving as a consultant to the Committee on Uniform Rules, and thus have first-hand knowledge of the Conference's valuable activities. The Committee on Uniform Rules concluded that uniformity was feasible and desirable in procedural rules on certain matters, and it drafted illustrative rules dealing with those matters. The Conference approved the Committee's conclusion, but without approval or disapproval of the illustrative rules. President's Conference on Administratrve Procedure, Report 14-36, 67-69 (1954).

${ }^{18}$ Pretrman, op. cit. supra note $\mathrm{I}$, at $47-5 \mathrm{I}$.

${ }^{10}$ See testimony of Judge Prettyman in Hearings Before the Subcommittee on Administrative Practice and Procedure of the Senate Committee on the Judiciary entitled "Federal Administrative Procedure," 86th Cong., 2d Sess. 8-18 (1960) [hereinafter cited as Federal Administrative Procedure Hearings].

${ }^{20}$ Committees of the Section of Administrative Law have, for example, worked informally with agencies on the revision of their procedural rules and otherwise on the improvement of their procedures. The Section membership includes, besides practising lawyers (many of whom have themselves had long experience in the agencies), lawyers now in the Government, including agency members, counsel, and hearing examiners, and teachers of law.

${ }^{21}$ Proceedings of the House of Delegates, 81 A.B.A. REP. 369,385 (1956).

${ }^{22}$ S. Res. 6r, 86th Cong., Ist Sess. (1959); S. Res. 234, 86th Cong., 2d Sess. (1960). See Subcomm. on Administrative Practice and Procedure of the Senate Comm. on the Judiciary, Administrative Practice and Procedure, S. Rep. No. 1484, 86th Cong., 2d Sess. (I960). 
House of Representatives, primarily through the Committee on Government Operations and the Subcommittee on Legislative Oversight of the Committee on Interstate and Foreign Commerce; and more activity in the House is expected. ${ }^{23}$ Representatives of the Association have actively assisted the work of these congressional committees both in investigating the performance of agency functions and in considering means of improvement.

The American Bar Association first dealt specifically with the field of administrative law in 1933, when it created a Special Committee on Administrative Law under the chairmanship of Louis G. Caldwell. ${ }^{24}$ That Committee continued, under the chairmanship of Mr. Caldwell, Col. O. R. McGuire, Dean Roscoe Pound, and Carl McFarland, until the enactment of the Administrative Procedure Act of 1946, when it was succeeded by the Section of Administrative Law. ${ }^{25}$ The Section has dealt with the whole range of questions that the field of administrative law includes. ${ }^{26}$ Operating initially through specially-informed committees, it has observed and appraised the Administrative Procedure Act of 1946 in operation; it has dealt with problems arising out of new legislative proposals, sometimes supporting and sometimes opposing; ${ }^{27}$ it has originated proposals of its own for legislative and administrative action; and it has concerned itself also with the day-to-day operation of the various administrative agencies. ${ }^{28}$ All this provided a strong base for the Association's current legislative program.

\section{II}

\section{The American Bar Association's Legislative Program}

The legislative program found immediate stimulus in the reports issued in the spring of 1955 by the Commission on Organization of the Executive Branch of the Government, the Second Hoover Commission, and its Task Force on Legal Services and Procedure. I was at that time chairman of the Section of Admin-

\footnotetext{
${ }^{23}$ See, e.g., Special Subcomm. on Legislative Oversight of the House Comm. on Interstate and Foreign Commerce, Report, H.R. Rep. No. 2238, 86th Cong., 2d Sess. 41-42 (1961), recommending a permanent Subcommittee on Regulatory and Administrative Commissions. The House Committee on the Judiciary has set up in the 87 th Congress a Special Subcommittee on Administrative Procedure.

${ }^{24}$ Proceedings, 58 A.B.A. ReP. 4I, 197 (1933).

${ }^{25}$ Special Comm. on Administrative Law, Report, 7I A.B.A. ReP. 213 (1946). For an account of the Committee's activities during the intervening years, sufficient for present purposes, sec Comm. on the Administrative Court Proposal, Report app. $x$, "History of Federal Administrative Court Proposals in the American Bar Association," 3 AD. L. Bull. 78, 83 (1951).

${ }^{20}$ See, e.g., the account of the Section's consideration of the question of the feasibility and desirability of uniform rules of administrative procedure, in Uniform Rules, 7 AD. L. BuLL. 28-32 (1954); and cf. note I7 supra. The Section's Administrative Law Bulletin, published since 1949, reflects the wide scope of its activities.

${ }^{27}$ E.g., in I954-55, the Section opposed a proposal for transfer of jurisdiction of unfair labor practice cases from the NLRB to the federal district courts, partly on the ground that such transfer would impair the desirable uniformity of decision accomplished through centralized adjudication by the Board; and the House of Delegates concurred. 1955 Mid-Winter Meeting, Resolutions Proposed by Section Adopted by House of Delegates, 7 AD. L. Bulz. 43, 45 (1955); Jurisdiction of Unfair Labor Practice Cases, 8 id. at ig (I955); Proceedings of the House of Delegates, 80 A.B.A. REP. 39r, 399 (r955).

${ }^{28}$ See note 20 supro.
} 
istrative Law. Detailed consideration of these Hoover Commission reports became the immediate business of the Section, initially through study by Section committees of those aspects of the reports that directly affected the subjects of their special concern. Detailed consideration continued at the I955 annual meeting of the Section. The Council of the Section devoted an extended meeting to this subject, and all members of the Section were invited to participate; in addition, a full day of the Section membership meeting continued consideration of the reports. ${ }^{29}$ The discussion at the Section membership meeting was recorded and reproduced for use by those concerned with the continuing study.

Meanwhile, the President of the Association had appointed a Special Committee on Legal Services and Procedure, under the chairmanship of Ashley Sellers, on which I also had the privilege of serving. The Special Committee sought and obtained the assistance of sections and committtes of the Association that had had various aspects of the problems under study over the years, and the views of the administrative agencies and of other informed persons. ${ }^{30}$ With detailed study through subcommittees and extended consideration in full sessions, the Special Committee produced a report dated January $3^{1}, 1956,{ }^{31}$ proposing resolutions for adoption by the House of Delegates which would form the framework of a legislative program, and supporting those proposals with detailed comment.

The resolutions proposed by the Special Committee were adopted by the House of Delegates on February 20, $1956^{32}$ The first of these resolutions, taking cognizance in a preamble of both the Hoover Commission reports and the r954 report of the President's Conference on Administrative Procedure, proposed in general terms the matters dealt with in the following resolutions, including replacement of the Administrative Procedure Act of 1946 with a Code of Federal Administrative Procedure. ${ }^{33}$ Resolution 2 set forth matters to be taken into account in the new Code with respect to public information, rulemaking, formal adjudication, and judicial review. Resolution 3 recommended the establishment within the executive branch (but independent of any department or agency thereof) of what it referred to as an Office of Administrative Procedure and Legal Services, with a Division of

${ }^{20}$ See Plans for Annual Meeting, 7 AD. L. BuLl. II4 (I955); Program of Annual Meeting, id. at I73.

${ }^{30}$ For a list of those consulted, see appendix to Special Comm. on Legal Services and Procedure, Report, 8r A.B.A. REP. 49I, 53I-33 (1956). So far as concerns sections and committees of the ABA, the list is incomplete in the sense that officers of other sections and committees were themselves members of the Special Committee.

${ }^{31}$ Special Comm. on Legal Services and Procedure, Report, 8I A.B.A. REP. 49I (I956).

32 Proceedings of the House of Delegates, 81 A.B.A. REP. 369,37 I-84 (I956).

${ }^{33}$ The text of Resolution $I$ is as follows:

" $r$. Resolved, That the American Bar Association is of the opinion that a comprehensive reexamination should be undertaken at this time of the Administrative Procedure Act of 1946 and related matters, including detailed consideration of and provision for more adequate public information on the procedures and operation of Federal agencies, improvements in the processes of agency rule-making, better assurance of fair and expeditious hearing and determination of agency cases, and improvements in judicial review of agency action; and to these and other ends advocates replacing the Administrative Procedure Act with a Code of Federal Administrative Procedure and undertaking the other reforms set forth in the following resolutions." Special Comm. on Legal Services and Procedure, sttpra note 3I, at 49 I. 
Administrative Procedure, a Division of Hearing Commissioners, and a Division of Legal Services; subresolutions (3.1, 3.2, and 3.3) dealt with implementation by the Office of the proposals of the President's Conference on Administrative Procedure, administration by the Office of revised laws with respect to a corps of hearing commissioners, and a newly-to-be-established legal career service for civilian attorneys in the Government. Resolution 4 recommended the establishment, in the judicial branch, of specialized courts (or divisions of a specialized court) "to have original jurisdiction in specified cases ... . in areas presently subject to administrative action equivalent to judicial action in courts of general jurisdiction"; to such courts would be transferred (a) from the Federal Trade Commission and certain other agencies adjudication of cases in the trade practice field, (b) from the National Labor Relations Board adjudication of representation and unfair labor practice cases, and (c) "such other adjudicatory functions as the Congress may from time to time determine." Resolution 4.I recommended transfer of the Tax Court of the United States to the judicial branch. Resolution 5 dealt with representation before agencies by lawyers and non-lawyers, including provision for disciplinary control by a Federal Grievance Committee of lawyers engaged in such practice. Resolution 6 dealt with legal services in the Department of Defense. ${ }^{34}$ Resolution 7 conferred on the Board of Governors (which acts for the American Bar Association during intervals between the semi-annual meetings of the House of Delegates) authority to determine how the first six resolutions should be implemented. ${ }^{36}$ The Board of Governors conferred implementing authority on the Special Committee on Legal Services and Procedure. ${ }^{36}$

To carry out the drafting of legislation, the Special Committee set up advisory groups. Each of the advisory groups, under the chairmanship of a member of the Special Committee, included representatives of interested sections and committees of the Association. The drafting process varied among the advisory groups; the

84 The function of implementing Resolution 6 was ultimately withdrawn from the Special Committec on Legal Services and Procedure at its own instance. Special Comm. on Legal Services and Procedure, Report, 84 A.B.A. Rep. 427, 429-30 (1959); Proceedings of the House Delegates, 85 id. 297, 334 (I960). Since the subject matter is in any event remote from the purposes of this paper, I shall have no more to say about that resolution.

${ }^{85}$ As originally proposed by the Special Committee, Resolution 7 called for its discharge; but that provision was eliminated by the House of Delegates.

${ }^{80}$ Board of Governors, Report, 8r A.B.A. REP. 210 (1956). The text of the Board's resolution is:

"Resolved, That, until further order, the Board of Governors of the American Bar Association hereby confers upon the Special Committee on Legal Services and Procedure authority to take such action as may be necessary to seek the implementation of the recommendations proposed by said committee in its report of January 31, I956, as adopted by the House of Delegates on February 20, 1956, such authority to include, but not to be limited to, the right to appear before Congressional committees in support of the principles approved by the action of the House, to participate in the drafting of necessary legislation to implement said principles, and to delegate to other appropriate committees and sections of the Association the responsibility of carrying out such specific tasks in connection therewith as the Special Committec may determine to be proper.

"Resolved, Further, That the authority hereby conferred upon the Special Committee may be cxercised by a subcommittee of not more than six of its members to be designated by its Chairman, which subcommittee shall act primarily as a steering committee with the remaining members of the Special Committee acting in an advisory capacity." 
Section of Administrative Law was enlisted by the Advisory Group on Resolution 2 to prepare the initial draft of the proposed Code of Federal Administrative Procedure; other advisory groups prepared their own initial drafts. However the initial drafts were prepared, they were studied and revised by the advisory groups and, in turn, by the full Special Committee, with interchanges of view between the groups and the Committee. ${ }^{37}$ Having participated in this process, ${ }^{38}$ I can say that I have never known a more diligent and responsible effort of legislative draftsmanship.

With the completion of the drafting process, the Special Committee on Legal Services and Procedure took on the function of seeking in behalf of the Association enactment of the proposed legislation. For this purpose, there were created by the Board of Governors ad hoc special committees to deal severally with the several bills, and the Special Committee on Legal Services and Procedure was reconstituted to consist of its chairman and the chairmen of the several ad hoc committees. ${ }^{39}$ The present ad hoc committees are the Committees on the Code of Administrative Procedure, on Courts of Special Jurisdiction, on the Federal Administrative Practice Act, and on a Permanent Congressional Committee on Administrative Procedure. The last-named, it will be observed, is not, like the others, concerned with a particular bill; it was created by the Board of Governors in $195^{40}$ to carry further the Association's advocacy of the establishment of such a congressional committee, ${ }^{41}$ and, having this function, it was thought appropriate that it should be a constituent of the Special Committee on Legal Services and Procedure.

I should mention also one further recent activity of the Special Committee on Legal Services and Procedure not included in the recommendations made by the Committee in its January 3r, r956, report. In February 1959, the House of Delegates authorized the Special Committee and the Section of Administrative Law to further the adoption of legislation to deal with ex parte influence on agency adjudication. ${ }^{42}$ The Special Committee delegated its part in this enterprise to the constituent ad hoc Committee on the Federal Administrative Practice Act (as authorized by the House of Delegates). As is well known, this has been for the last several years a subject of

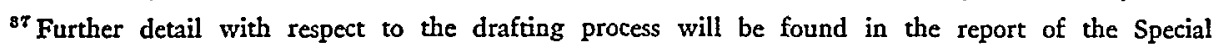
Committee to the I957 Midyear Meeting of the House of Delegates. Special Comm. on Legal Services and Procedure, Report, 82 A.B.A. Rep. 485 (1957).

${ }^{38}$ During the drafting process, I was chairman of the Advisory Group on Resolutions 4 and $4 . \mathrm{I}$, and served also as a member of the Special Committee and of its steering committee. See last paragraph of note 36 supra. During the initial period of the Special Committee's activity, I had been chairman of a subcommittee dealing with the question of revising the Administrative Procedure Act of 1946 and a member of the drafting committee charged initially with preparing the report of the Special Committee dated Jan. 31, I956.

${ }^{30}$ Board of Governors, Report to the House of Delegates, 82 A.B.A. REP. 214, 215-16 (1957). See also the report of the Special Committee to the House of Delegates at the 1957 Annual Meeting. Special Comm. on Legal Services and Procedure, Report, 82 A.B.A. REP. 346 (1957). As I have noted, note 34 supra, the ad hoc Committee on Defense Department Legal Services was ultimately abolished at its own request and the request of the Special Committee.

${ }^{10}$ Board of Governors, Report to the House of Delegates, 83 A.B.A. REP. 273, 276 (1958).

¿Iee note 21 supra and related text.

${ }^{13}$ Proceedings of the House of Delegates, 84 A.B.A. REP. 502, 522-25 (1959). 
active consideration in the Congress ${ }^{43}$ and of widespread public interest. I shall not deal with it in this paper, though I shall have occasion to mention it in the course of comment on the separation-of-functions provision of the proposed Code of Federal Administrative Procedure, which concerns internal ex parte influence.

Before I take up specific discussion of the Association's legislative program, there are general points to be made.

We should like our program to be judged by what we propose and not by what someone else has proposed. Because our current legislative program found its immediate stimulus in the Hoover Commission reports, there has been a tendency to attribute to the American Bar Association everything that the Hoover Commission or its Task Force proposed and the rationale advanced by them for everything they proposed. As the later discussion will make clear, such attribution is incorrect.

We should hope also that criticism of our proposals would avoid use of tendentious and ambiguous words like "judicialization" and "formalization," and would be directed to the merits in detail of what we actually propose. ${ }^{44}$

In my 1942 report to the Governor of New York, I wrote: ${ }^{45}$

What I have referred to as the democratic safeguards and standards of fair play have been developed over the course of centuries under the protection of the courts of England and America. While the forms of judicial procedure are not to be literally applied in the administrative field, the experience which they reflect can furnish criteria that may be usefully applied in many instances.

The teachings of judicial experience, that is, may be usefully suggestive in considering the most appropriate procedures for administrative adjudication; they will not be conclusive. That is the approach reflected in the American Bar Association's proposals. If one proposal or another is thought, on the merits, to follow a judicial analogy too far, there is a legitimate subject for discussion. Discussion and understanding will not be furthered by general assertions that the proposals are for "judicialization" of the administrative process; general assertions that the proposals are directed to "formalizing" administrative procedures ${ }^{46}$ are in the same category.

${ }^{48}$ See, e.g., S. 2374, H.R. 6774, 86th Cong., Ist Sess. (1959); H.R. I273I, 86th Cong., 2d Sess. (r960); House Comm. on Interstate and Foreign Commerce, Independent Regulatory Agencies Act of rg60, H.R. REP. No. 2070, 86th Cong., 2d Sess. (1960); H.R. 351, 87th Cong., Ist Sess. (r96I); Hearings Before the Subcommittee on Administrative Practice and Procedare of the Senate Committee on the Judiciary entitled "Administrative Procedure Legislation," 86th Cong., Ist Sess. (1959) [hereinafter cited as Administrative Procedure Legislation Hearings]; Subcomm. on Administrative Practice and Procedure of the Senate Comm. on the Judiciary, Administrative Practice and Procedure, S. REP. No. 1484, 86th Cong., $2 \mathrm{~d}$ Sess. (1960); Hearings Before the Subcommittee on Legislative Oversight of the House Committee on Interstate and Foreign Commerce on Investigation of Regulatory Commissions and Agencies, 85th Cong., 2d Sess. (1958); id., 86th Cong., Ist Sess. (1959); Hearings Before the Subcommittee on Legislative Oversight of the House Committee on Interstate and Foreign Commerce on Ex Parte Communications and Other Problems (Federal Power Comm'n), 86th Cong., 2d Sess. (1960).

"For a different reason, I do not agree with too frequent references to "due process" in behalf of the Association's proposals. Many forms of procedure are consistent with constitutional due process, and the most satisfactory may call for much more than constitutional due process alone would require.

¿5 BenjaMin 12

${ }^{4}$ See note 9 supra and related text. 
I should point out here, lest it be lost in the later discussion regarding the proposed Code of Federal Administrative Procedure, the basic point that the Administrative Procedure Act of 1946 does not require, and the Code would not require, formal administrative hearing procedures in any instance; they provide only what the procedures should be if the Congress by statute, or the Constitution, ${ }_{9}^{47}$ requires that there be a formal hearing. Thus, if it is thought that inquiry by the Civil Aeronautics Board into the desirability of new routes and new services would be better carried out through some type of informal proceeding, ${ }^{48}$ the Congress could presumably so provide. ${ }^{49}$

A final preliminary point: What I have already said about the American Bar Association's other activities (for example, through the Section of Administrative Law, in support of the President's Conference on Administrative Procedure, and in encouraging increased activity by the Congress in the field of administrative procedure) should be enough to make it clear that the Association's legislative program is not advanced as sufficient in itself to solve all the problems of federal administrative procedure. The Association does believe that its legislative program is sound and will help immensely in moving towards valid solutions. Indeed, the first element of the program that I propose to discuss-which includes the proposal for an independent Office of Administrative Procedure ${ }^{50}$-looks to setting up what would in itself be a dynamic force for continuing improvement in administrative procedure.

III

\section{The Federal Administrative Practice Act}

The Federal Administrative Practice Act ${ }^{51}$ is based on Resolutions 3 and 5 of the resolutions adopted by the House of Delegates of the American Bar Association on February 20, 1956. It has four major titles: title I-"Office of Federal Administrative Practice"; title II-"Hearing Commissioners"; title III-"Legal Career Service"; title IV-"Admission to and Control of Practice." Titles III and IV (and title V"General Provisions"), important as they are, have not sufficient bearing on the subject of this symposium to justify discussion here. I shall, then, confine myself to titles I and II.

Proposals for an Office of Administrative Procedure ${ }^{52}$ date back to the report of the Attorney General's Committee on Administrative Procedure, which recom-

${ }^{47}$ See Wong Yang Sung v. McGrath, 339 U.S. 33, 50-5I (I950).

${ }^{48}$ See James M. Landis, Report on Regulatory Agencies to the President-Elect 4 T-42 (i960) [this report has been published as a committee print by the Subcommittee on Administrative Practice and Procedure of the Senate Committee on the Judiciary, 86th Cong., 2d Sess. (1960)]. Cf. Friendly, $A$ Look at the Federal Administrative Agencies, 60 CoLum. L. REv. 429, 442 (1960).

${ }^{10}$ I would see no constitutional impediment here.

to The proposed statute, the Federal Administrative Practice Act, provides for an "Office of Federal Administrative Practice." In view of the history and present status of other similar proposals, it will be more convenient to refer to this as an "Office of Administrative Procedure," or simply as the "Office"; and $I$ accordingly do so in this paper.

${ }^{21}$ S. 600, 86th Cong., Ist Sess. (1959); H.R. 349, 87th Cong., Ist Sess. (I96r).

${ }^{62}$ See note 50 supra. 
mended an Office headed by a board composed of a justice of the United States Court of Appeals for the District of Columbia, the Director of the Administrative Office of the United States Courts, and a Director of Federal Administrative Procedure to be appointed by the President with the advice and consent of the Senate. ${ }^{58}$ The Committee suggested advisory committees to the Director, composed of representatives of the agencies and of the public. ${ }^{54}$ As to functions, the Committee wrote: ${ }^{\text {55 }}$

In general, it should be the major function of the Director to examine critically the procedures and practices of the agencies which may bear strengthening or standardizing, to receive suggestions and criticisms from all sources, and to collect and collate information concerning administrative practice and procedure. ... [N]ot the least of the difficulties which have confronted the orderly development and understanding of administrative procedure is the absence of detailed information and study. ... Knowledge and regularization of procedures should go far toward creating that confidence in the administrative process which is necessary for its successful functioning.

In addition to these general duties of investigation and collection of data, the Committee recommends . . . that there be vested in the Office of Administrative Procedure important duties with respect to the selection and removal of hearing commissioners. . . .

The proposals of the American Bar Association in the Federal Administrative Practice Act bear strong resemblance to the proposals of the Attorney General's Committee. The Office would be "an independent agency in the executive branch of the Government" (section IOI). At the head of the Office would be the Director; he and a Deputy Director would be appointed by the President with the advice and consent of the Senate (section r02). ${ }^{56}$ The Director would designate an advisory committee composed of representatives of the agencies and of the public (section 108). The Act spells out functions in more detail than the Committee did, and in some respects (as with functions under the Federal Register Act) goes beyond what the Committee recommended; but there is still strong resemblance. Under section Iro(b) of the Act, the Office would:

(r) carry on continuous studies of and make recommendations regarding the adequacy of the procedures by which agencies determine the rights, duties, or privileges of persons;

(2) carry on continuous studies of and make recommendations regarding the adequacy of the procedures by which agencies exercise rulemaking and adjudicatory functions;

(3) carry on continuous studies of the adequacy of public information practices and procedures of the agencies related to rulemaking and adjudication;

(4) initiate consultative and cooperative efforts among the agencies and interested organizations for development and adoption, wherever feasible and appropriate, of uniform rules of practice and procedure;

${ }^{53}$ Attorney General's Comm. on Administrative Procedure, Administrative Procedure in Government Agencies, S. Doc. No. 8, 77th Cong., Ist Sess. I23 (194I).

${ }^{54}$ Ibid.

${ }^{8 x}$ Id. at $523-24$.

${ }^{50}$ The Director would be appointed for a term of ten years and the Deputy Director for five years (\$ I03). Under the Director, each division of the Office dealing with one of its several major functions would be supervised by an Assistant Director, appointed by and reporting to the Director (\$ ro4). 
(5) receive complaints regarding matters of practice and procedure and make investigations or recommendations as deemed appropriate;

(6) furnish assistance and advice upon request of any agency;

(7) examine the state of hearing dockets of agencies, secure information as to the agencies' need of assistance and prepare statistical data and reports on agency proceedings;

(8) perform the duties and functions vested in the Administrator of General Services and Federal Register Division under the Federal Register Act;

(9) study and make recommendations upon methods of organization appropriate for the separation of agency functions.

And under section $\mathrm{IIO}(\mathrm{d})$, the Office would undertake special studies and make recommendations on subjects including:

(r) ways and means of minimizing undue delay and expense of agency proceedings;

(2) the feasibility of establishing a Federal reporter service covering agency decisions with current advance sheets, and a reporter service for agency practice and procedure decisions;

(3) methods for simplifying and reducing the cost of the agency hearing records and of agency records before the courts of appeal including incorporation, physically or by reference, without further printing of agency decisions and initial decisions;

(4) the feasibility of making the Code of Federal Regulations current by some looseleaf system and making the whole service or any part or subpart thereof available nationwide on subscription;

(5) the feasibility of correlating and annotating agency regulations with the related substantive provisions of statute or treaty and a periodic recodification of the rules for deletion of stale or obsolete regulations;

(6) procedures especially appropriate for multiparty proceedings, particularly in the fields of ratemaking or price regulation;

(7) procedures and methods for effective participation by the public in agency rulemaking proceedings;

(8) the desirability of a uniform statute for judicial review of agency proceedings and the adequacy of statutory provisions on judicial review;

(9) promulgation of a single code of rules on those subjects which are found acceptable for uniform application among the several agencies;

(10) the adequacy of agency law libraries and their management to improve the efficiency of Government legal services;

(II) improvements in the form of agency applications, reports or questionnaires of the type which relate to agency proceedings.

In further (though not complete) resemblance to the recommendations of the Attorney General's Committee, ${ }^{57}$ the Director would, under title II of the Act, also administer new provisions with respect to a corps of hearing commissioners (a subject with which I shall deal below).

Meanwhile, two other proposals for an Office had been made-one by the President's Conference on Administrative Procedure, ${ }^{58}$ and the other by the Second

\footnotetext{
${ }^{57}$ For the full recommendations of the Attorney General's Committee with respect to hearing commissioners, see Attorney General's Comm. on Administrative Procedure, supra note 53, at 46-51.

${ }^{88}$ President's Conference on Administrative Procedure, op. cit. supra note I7, at 3-4, 46-48.
} 
Hoover Commission. ${ }^{59}$ The functions proposed, though in some respects more limited, were similar to some of those I have been discussing; ${ }^{60}$ but the President's Conference and the Hoover Commission differed from the Attorney General's Committee and the American Bar Association in recommending that the Office be in the Department of Justice.

In I957, an Office of Administrative Procedure was set up in the Department of Justice by order of the Attorney General..$^{01}$ As John F. Cushman, then Director of the Office, testified before the Senate Subcommittee on Administrative Practice and Procedure, this was an "interim" or "experimental office," which would "fill the gap . . . until such time as the Congress saw fit to act."62 The experiment has been valuable in many ways, as the three annual reports so far issued by the Office attest; $^{63}$ but the question remains as to the most effective form of organization of an Office.

The Office proposed by the American Bar Association would have no power to compel action by any of the administrative agencies with whose procedures it would deal; its powers would be limited to examination and to advice and persuasion. ${ }^{64}$ It is, we believe, essential to the most successful operation of such an Office that the Director have status equal to, and be independent of, those with whom he will deal, and that he have authority to examine into whatever he finds relevant to his inquiries. In support of these views I can cite Walter Gellhorn, Director of the Attorney General's Committee, who testified before the Senate Subcommittee on Administrative Practice and Procedure: ${ }^{65}$

I think that the director of that office should be a person of great stature and significant power, with the capacity to obtain all papers and files bearing on any matters that he was concerned with looking into ....

My own experience in New York bears out these views. ${ }^{66}$ My study there was as

${ }^{80}$ Comp'n on Organization of the Executive Branch of the Government, Report on Legal Services and Procedure 82-84 (I955) [hercinafter cited as Hoover Comm'n Report].

${ }^{\circ 0}$ See President's Conference on Administrative Procedure, op. cit. supra note 17, at 3, recommending that:

“... the Office perform the following functions:

"(i) carry on continuous studies of the adequacy of the procedures by which Federal agencies determine the rights, duties, and privileges of persons;

"(ii) initiate cooperative effort among the agencies and their respective bars to develop and adopt as far as practicable, uniform rules of practice and procedure;

"(iii) collect and publish facts and statistics concerning the procedures of the agencies;

"(iv) assist agencies and this Conference in the formulation and improvement of their administrative procedures."

${ }^{21}$ Order r42-57, 22 Fed. Reg. 998 (1957). The order stated the functions of the Office in almost the same terms as those proposed by the President's Conference, quoted in note 60 supra.

${ }^{82}$ Administrative Procedure Legislation Hearings, supra note 43 , at $213,220$.

${ }^{3}$ Office of Administrative Procedure, Office of Legal Counsel, U.S. Dep't of Justice, Ann. REP. (1957, 1958, 1959).

os The same is true of the other recommendations I have discussed, except that the Hoover Commission would have given some powers of compulsion-e.g., with respect to "simplification, clarification, and uniformity of rules." HOOVER COMM'N REPORT 83.

${ }^{05}$ Federal Administrative Procedure Hearings, stupra note 19, at 120.

os In my report to the Governor, I made, independently of the Attorney General's Committec though 
a representative of the Governor under what is known as the Moreland Act, ${ }^{67}$ which authorizes the Governor, through persons appointed by him, to examine and investigate the affairs of any state agency, and confers power of subpoena (which I never used). I am sure that my status, equal to that of the administrators with whom I dealt, and my authority to examine whatever I thought relevant, had much to do not only with my ability to carry out effectively the study with which I was charged, but also with the degree to which my recommendations were effective.

The British view is, I think, also relevant. The Franks Committee recommended, in a somewhat narrower field, the setting up of a Council on Tribunals to be appointed by the Lord Chancellor and the Secretary of State for Scotland; ${ }^{68}$ and this recommendation was given effect in the Tribunals and Inquiries Act, $195^{86}{ }^{60}$

I have mentioned before the momentarily-expected organization of an Administrative Conference of the United States, and the support that the American Bar Association accords to that project. Warm as our welcome is, we must at the same time state an emphatic view that an Administrative Conference cannot take the place of an independent Office of Administrative Procedure; that the work of the two organizations would be complementary, and that to resort to either one, to the exclusion of the other, would be to lose much of the value that the other could contribute.

The President's Conference on Administrative Procedure, in 1953 and r954, was predominantly a conference of the agencies; and when the organization of the new Administrative Conference becomes known, it will doubtless appear that the agencies will have an important, if not a predominant, part there also. Self-examination and self-criticism are of the greatest value, but they cannot take the place of the detached examination and detached criticism that an independent Office of Administrative Procedure would supply; cross-criticism in a conference of equals of like position is perhaps the least likely to be advanced effectively or accepted.

I have had experience in New York with a somewhat similar organization, the Conference of Administrative Counsel constituted in I948 of the general counsel (or their representatives) of the State's agencies having most to do with adjudication, which met periodically to consider procedural questions of mutual concern. That Conference, in my judgment, fell far short of what my proposed Division of Administrative Procedure ${ }^{70}$ could be expected to accomplish.

The difference in effectiveness is not due solely to the difference between selfexamination and self-criticism and detached examination and detached criticism. Conferences of this kind cannot engage in the continuous, day-to-day work that shortly thereafter, a like recommendation for a Division of Administrative Procedure in the Executive Department of New York. BENJAMTN I8-21.

${ }^{\circ 7}$ N.Y. Executive LAW $\$ 6$ (then $\S 8$ ).

${ }^{\circ 8}$ CMND. No. 218, at 10, 30-3I.

${ }^{60} 6$ \& 7 Eliz. 2, c. 66. For an account, by a member of the Council, of its activities during its first year, see Wade, supra note 6; see also Council on Tribunals, First Report (ig6o).

${ }^{70}$ See note 66 supra. 
would be expected of an Office. The New York Conference of Administrative Counsel met, generally, monthly. The new Administrative Conference of the United States would, it is likely, meet only twice a year. ${ }^{71}$ Committee work, and even the likely provision for a Council, would still, in my view, not supply the necessary continuity.

It appears likely also that the organization of the new Administrative Conference will include transfer to the Conference, as its secretariat, of the present Office of Administrative Procedure in the Department of Justice. ${ }^{72}$ Certainly the Conference will need a permanent secretariat, and transfer of the Office from the Department of Justice will make excellent provision in that regard. It could well continue, in its subordinate status as secretariat, its statistical work and some of its other present activities. But in other respects its transfer to a subordinate position in the Conference would make even more urgent the setting up of the independent Office of Administrative Procedure that the American Bar Association advocates.

I return now to the functions of our proposed Office, under title II of the Federal Administrative Practice Act, with respect to hearing commissioners.

With a "grandfather clause" for incumbent trial examiners (section 202), the Director would fix qualifications for hearing commissioner positions, subject to statutory minima (section 204); he would appoint qualified hearing commissioners and, upon consultation with the agency concerned, assign them to authorized hearing commissioner positions in the several agencies (section 203). ${ }^{73}$ Provision would be made for tenure during good behavior, and for removal by the Director (on his own motion or on complaint) only for good cause established after opportunity for hearing, with opportunity for judicial review (sections 205, 207). Substantial compensation would be provided for (section 206). An old argument about rotation of cases among trial examiners ${ }^{74}$ would be resolved by requiring that each agency, upon consultation with the Director, adopt regulations for the systematic assignment of cases among hearing commissioners (section 2II).

This is, I believe, a sound and workable solution of problems of long standing. ${ }^{75}$ Its basic purpose is to achieve what Dean Landis calls "the extremely important goals of maintaining the independence and integrity of the hearing examiners and of evolving a corps of highly qualified examiners. ..."7o (I shall have more to say about the functions of hearing commissioners in the portion of this paper dealing with the proposed Code of Federal Administrative Procedure.) The Association

${ }^{71}$ See Judge Prettyman's testimony, Federal Administrative Procedure Hearings, supra note 19, at 9.

${ }^{72}$ Id. at I7; Mr. Cushman's testimony, Administrative Procedure Legislation Hearings, supra note 43 , at 2I7; Landis, op. cit. supra note 48 , at 73,87 .

${ }^{78}$ Such assignments would be "on a continuing basis subject only to reassignment by the Director as efficiency of operations or the needs of the service may require" ( $\$ 203$ ).

74 See Ramspeck v. Federal Trial Examiners Conference, 345 U.S. I28 (1953).

${ }^{75}$ I need not deal here with disagreements within the President's Conference of $1953-54$ as to how the problems should be solved, or with other recommendations beyond those of the Attorney General's Committee to which I have already referred (see notes 55 and 57 stupra and related text).

${ }^{70}$ LaNDis, op. cit. supra note 48 , at 73 . 
agrees with Dean Landis also that "the Civil Service Commission is not fundamentally organized to handle this problem."77 We part with Dean Landis only when he suggests that the functions to be removed from the Civil Service Commission should be assigned to the secretariat of the Administrative Conference of the United States. ${ }^{78}$ The necessarily subordinate position of the secretariat in a Conference consisting largely, if not predominantly, of representatives of the agencies would, we believe, impair the proper independence of the hearing commissioners which Dean Landis agrees with us in seeking.

Since I have been dealing with means of assuring the high quality of personnel engaged in administrative adjudication (and to some extent in rulemaking), it is appropriate to mention here another recent non-legislative activity of the American Bar Association. In 1957, the Association set up a Special Committee on Administrative Agency Appointments "to promote the nomination and confirmation of competent lawyers as members of federal independent agencies and commissions and to oppose the nomination and confirmation of lawyers deemed by it to be not sufficiently qualified."70 It had first been ascertained that the White House would welcome this step. The Committee acts only on the request of the Executive, and acts also in recognition of the fact that not all agency members will be lawyers and that additional qualifications besides legal competence are often required of agency members who are lawyers.

\section{IV}

\section{SPecialized Courts}

Resolution 4 of the resolutions adopted by the House of Delegates recommended (it will be remembered) the establishment, in the judicial branch, of specialized courts (or divisions of a specialized court) "to have original jurisdiction in specified cases .... in areas presently subject to administrative action equivalent to judicial action in courts of general jurisdiction."80 The rationale of this recommendation is stated in the comment on Resolution 4 in the report dated January 31, I956, of the Special Committee on Legal Services and Procedure, from which I quote: ${ }^{81}$

Where the machinery of administrative action is essentially the machinery of litigation and adjudication, in substance equivalent to judicial adjudication, the arguments for a full separation of functions are strongest and those against that course weakest.

The primary argument for transfer of such adjudicatory functions from agencies to courts is that litigation and adjudication, as such, can be done better by judicial than by

${ }^{7 z} \mathrm{lbid}$.

${ }^{78} 1 d$. at 73,87 .

${ }^{70}$ Board of Governors, Report to the House of Delegates, 82 A.B.A. REP. 214, 218 (1957); see also as to this and the following text, Special Comm. on Administrative Agency Appointments, Report, 83 A.B.A.Rep. 420 (1958).

${ }^{\text {Bo }}$ See page 210 supra.

${ }^{81}$ Special Comm. on Legal Services and Procedure, Report, 8I A.B.A. Rep. 49I, 513 (I956). 
administrative bodies, with better assurance of considered action and a greater confidence on the part of the litigants that they are being impartially dealt with.

The primary argument against such a separation of functions is that it would unduly impede administrative responsibility and effectiveness. That argument is entitled to prevail where administrative action is essentially regulatory. The argument is, however, not properly applicable where the administrative action is in essence not regulatory but adjudicatory in the judicial sense and where such adjudication is not an integral part of a larger regulatory process.

The argument is made, also, that transfer of adjudicatory functions to the courts would be at the expense of an expertness in adjudication in specialized fields. That argument is met by vesting adjudication in such specialized fields in specialized courts. Specialized expertness can, moreover, be furthered in appropriate instances through the process of specialized litigation in which the administrative agency, familiar with the field and with adequate powers of investigation, can present all relevant factors for consideration by the specialized court.

The dividing line suggested by the recommended resolution is between functions essentially adjudicatory in the usual sense and those essentially regulatory. The two areas of adjudication presently recommended for transfer to a specialized court or courts fall within the first category. Other transfers should be effected as the Congress explores the field and finds other adjudicatory functions to be within that category.

The rationale, in brief, is that courts and court procedure (including the procedural treatment of the parties) are better adapted to adjudication than are agencies and agency procedure, and that the combination in an agency of the functions of litigation and adjudication is not acceptable as a matter of policy in such instances (though it is justified where the proper and effective conduct of a regulatory function requires it).

The Special Committee report, and Resolution 4 of the House of Delegates, had left open the question whether there should be a single specialized court, with divisions, or several specialized courts. In the drafting process, the Advisory Group on Resolutions 4 and 4.I, and the Special Committee on its recommendation, decided in favor of separate courts; ${ }^{82}$ and there were therefore drafted a Trade Court Act ${ }^{88}$ and a Labor Court Act ${ }^{84}$ (in addition to a Tax Court Act ${ }^{85}$ pursuant to Resolution 4. I). Resolution 4 had decided that the Trade Court and the Labor Court should be (as the Tax Court is) courts of original jurisdiction, that is, trial courts, whose final orders and judgments would be subject to review by the United States Courts of Appeals. ${ }^{86}$ Some years before, the Section of Administrative Law, with the concurrence of the Section of Judicial Administration and the Standing Committee on Jurisprudence and Law Reform, had disapproved a bill to create an Administrative

${ }^{82}$ The Hoover Commission report had recommended a single Administrative Court of the United States, with a Tax Section, a Trade Section, and a Labor Section. Hoover Coma'N Report 86-88.

${ }^{88}$ S. 1275, 86th Cong., Ist Sess. (1959).

${ }^{84}$ S. 1273, 86th Cong., Ist Sess. (1959).

${ }^{85}$ S. 1274, 86th Cong., Ist Sess. (1959).

${ }^{80}$ The Hoover Commission report had left open the question whether the Trade Section and Labor Section of the Administrative Court it recommended should have original or appellate jurisdiction. HOOVER CONMM'N REPORT 88. 
Court of the United States which would have superseded the regular United States courts in the judicial review of administrative agency action; ${ }^{87}$ the present Special Committee report, citing these views and the like views of the Judicial Conference of the United States, concluded "that appellate jurisdiction had best be left unchanged." 88

The Court Acts themselves, being in the form of detailed amendments of title 28 of the United States Code, "Judiciary and Judicial Procedure," and of the statutes presently governing agencies whose adjudicatory jurisdiction (or some of it) would be transferred to the respective specialized courts, are difficult to read, and could not be adequately summarized within the confines of this paper. ${ }^{80}$ Nor do I think that any purpose would be served by statement here of detailed provisions with regard to the organization and procedure of these courts. The issue on which argument has centered is as to the soundness of the American Bar Association's basic position that adjudication of the character specified in Resolution 4 should be handled by specialized courts and not by agencies. It will, I think, be useful in this context to discuss, illustratively, the proposal embodied in the Trade Court Act. I select this for discussion partly because I am thus enabled, using the lawyer's expedient of incorporation by reference, to curtail greatly what I would otherwise have to say by referring to a recent article by my colleague Raoul Berger on the application of the Trade Court proposal to the Federal Trade Commission. ${ }^{90}$ I select the Trade Court proposal also because it seems to me, individually, to present the issue on the merits even more clearly than the Labor Court proposal (though in my report to the Governor of New York I recommended a similar division of the functions of the New York State Labor Relations Board between two independent boards).$^{91}$

Agency adjudicatory functions to be transferred from agencies to the newly-to-becreated United States Trade Court were selected by the Special Committee and its advisory group to conform to the Special Committee's carefully limited criteria. ${ }^{92}$ They include all the adjudicatory functions of the Federal Trade Commission (under section II of the Clayton Act, ${ }^{93}$ under section 5 of the Federal Trade Commission Act, and under other special acts, e.g., the Wool Products Labeling Act, administered by the Federal Trade Commission); they include also adjudicatory

${ }^{87}$ See The Proposal for an Administrative Court for Judicial Review (S. 488, 84th Cong.), 8 AD. L. Butc. 20 (1955); Report of Committee on the Administrative Court Proposal, 3 AD. L. Bull. 78 (195I). It should be noted that, since these views were not at the time submitted to the House of Delegates or the Board of Governors for action, they did not become official views of the American Bar Association.

${ }^{88}$ Special Comm. on Legal Services and Procedure, Report, 8I A.B.A. REP. 49I, 512 (1956).

${ }^{80}$ For convenient reference, the text of the Trade Court Act has been printed by the American Judicature Society, 4I J. AM. Jud. Soc'y 24 (I957).

${ }^{\mathrm{DO}}$ Berger, Removal of Judicial Functions from Federal Trade Commission to a Trade Court: A Reply to Mr. Kintner, 59 Mich. L. REv. I99 (1960). Mr. Berger is chairman of the ABA Special Committee on Courts of Special Jurisdiction.

${ }^{01}$ BENJaMIN 44 et seq., where at the same time I oppose transfer of adjudicatory functions of agencies involved in what is in a true sense regulatory action.

${ }^{0 .}$ See note 8x supra and related text.

${ }^{08}$ Clayton Act $\S$ II provides for proceedings to enforce compliance with $\S \S 2,3,7$, and 8 of that Act. 
functions of the Interstate Commerce Commission, the Federal Communications Commission, the Civil Aeronautics Board, and the Federal Reserve Board under section II of the Clayton Act, adjudicatory functions of the Civil Aeronautics Board under section r38I of the Federal Aviation Act (formerly section 4II of the Civil Aeronautics Act), and adjudicatory functions of the Secretary of Agriculture under sections 203, 204, and 205 of the Packers and Stockyards Act. They exclude, on the other hand, other adjudicatory functions the inclusion of which had been recommended by the Hoover Commission Task Force. ${ }^{94}$

The adjudicatory functions to be transferred to the Trade Court concern unfair, deceptive, and discriminatory trade practices, unfair methods of competition, restraint of trade, and the like. The issues litigated in such cases are familiar justiciable issues. The machinery of present agency action in dealing with these issues is the machinery of litigation and adjudication. In such litigation and adjudication the agencies do not "regulate" or "administer" in any sense in which I can understand those words.

In every case in the Trade Court, the agency whose adjudicatory jurisdiction had been transferred to the Court would be the petitioner. ${ }^{95}$ The present agency functions of investigation (of particular cases and general fields), of determining which cases should be litigated, and of preparing and presenting those cases in litigation would be left undisturbed. These functions would be carried on more effectively by an agency concerned with them alone, and not involved also in the conflicting function of adjudication. In the course of litigation, the expertness of the investigating and litigating agency could be brought to bear fully in its presentation to the Court.

As to adjudication, it is clearly better done by a court, whose business is adjudication, than by an agency in which that is only one of diverse functions. Courts would deal better not only with the substance of adjudication, but also with litigating procedures. I refer for example to a proceeding, discussed in Raoul Berger's article, ${ }^{96}$ in which the Federal Trade Commission vacated a stipulation which had been entered into with the approval of the trial examiner. The Commission noted that a stipulated limitation of proof might interfere with the success of "counsel supporting the complaint" ${ }^{\prime 27}$ in establishing his case; and, equating his success with "the public interest," it set the stipulation in that regard aside. This must, I believe, be shocking not only to lawyers. It may be asked, also, how parties are to be expected to expedite cases by stipulation if any part of a stipulation that favors them may later be set aside on such a ground.

24 Comm'n on Organization of the Execttive Branch of the Government, Task Force Report on Legar Services and Procedure 380, 391-92, 392-93, 393-94, 394-95 (1955) [hereinafter cited as TASK Force RePORT].

${ }^{25}$ The jurisdiction (in' the district courts) of actions by the United States under Clayton Act $\$ 15$, and the jurisdiction of private actions under $\S 16$, would not be transferred to the Trade Court.

${ }^{\circ B}$ Berger, supra note 90, at 210-11.

${ }^{97}$ I have always been struck by this self-conscious way of referring to the Commission's counsel litigating before it. 
I have one further comment regarding procedure: It has been argued, especially in behalf of the Federal Trade Commission, ${ }^{98}$ that to transfer the adjudicatory function to a court would impede the disposition of cases by voluntary compliance, stipulation, or consent order, a settlement process which now disposes of a large proportion of Federal Trade Commission cases. I see no reason why proper settlement of cases should not continue as effectively after transfer of the adjudicatory function to the Trade Court; and I note the frequency of consent decrees in antitrust litigation by the Department of Justice in the courts. If there would be any reduction in the number of settlements, it could only be because of pressure now implicit in the fact that the agency that prosecutes will ultimately decide, and thus holds the sword of ultimate adjudication over those from whom it seeks consent settlements. If that is the cost of more settlements, the cost is too high. This was among the factors supporting my own 1942 recommendation for the separation between two independent boards of the functions of the New York State Labor Relations Board. ${ }^{98}$

I have stated at the beginning of this section the rationale that supports the Association's Trade Court proposal. I should add here that this proposal is not based on the circumstance, relied on to some extent by the Hoover Commission Task Force, ${ }^{100}$ that cease-and-desist orders resemble the injunctive relief granted by courts. ${ }^{101}$

I have voiced above ${ }^{102}$ objection to the charge that the American Bar Association proposes "judicialization" of the administrative process. Certainly the proposals for transfer to specialized courts of carefully-limited instances of administrative adjudication are proposals for judicialization. They are not, however, proposals for judicialization of what in my view can properly be called an "administrative process."

\section{V}

\section{The Code of Federal Administrative Procedure}

The proposed Code of Federal Administrative Procedure ${ }^{103}$ implements Resolutions I and 2 of the House of Delegates. ${ }^{104}$ The Code reflects a responsible and considered effort of draftsmanship, informed by more than a decade of experience under the Administrative Procedure Act of 1946, which it would supersede. The I946 Act was never presented as a final solution of all the problems with which it dealt, but only as a major step towards solution, which would be subject to reappraisal in the light of experience. Nor is the Code itself presented by the American Bar

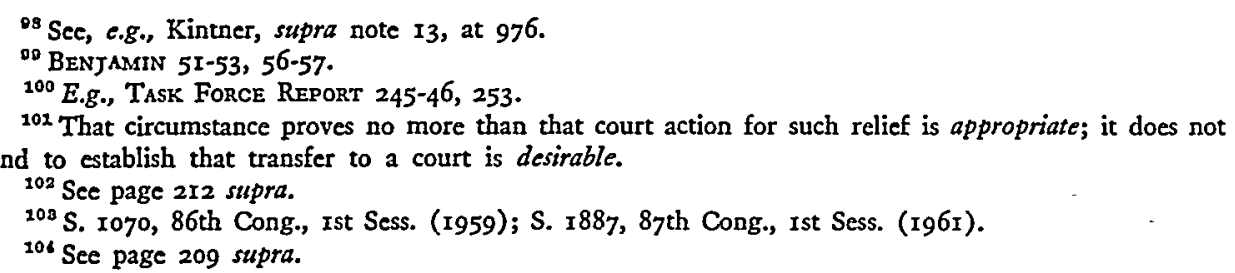


Association as a final text, to be accepted without change; ${ }^{105}$ nobody expects a statute of this scope to come out of the Congress in the exact form in which it was introduced. ${ }^{108}$ We welcome suggestions; and our Committee on the Code has already concluded that some suggestions for revision, made since the Code was introduced, should be accepted. But if the Code is not to be enacted in its exact initial form, it is at the very least a sound framework for needed revision of the 1946 Act.

It has been argued, in agency comment on our bill, that any changes in the I946 Act should be made by specific amendments, rather than by the general revision that we propose. General revision, the argument is, would create uncertainties and induce litigation. This argument is inconsistent with the commendable practice of agencies themselves in periodic complete revision of their own procedural rules. It assumes, moreover, more present certainty than there in fact is; the number of court decisions dealing with the interpretation and effect of the 1946 Act is large. Piecemeal amendment would, I suggest, do more to create uncertainties and inconsistencies ${ }^{\mathbf{1 0 7}}$ than one single effort of consistent and precise draftsmanship.

In August 1959, the Senate Committee on the Judiciary requested agency comment on the proposed Code. The comment, received by the late spring of 1960 , was made available by the Senate Subcommittee on Administrative Practice and Procedure to our Committee on the Code. We concluded that we should have assistance in full and objective consideration of the agency comment, which would be useful to the Senate Subcommittee as well as to us. To that end, we retained three professors of law as a Committee of Consultants, ${ }^{108}$ who could begin their detailed work during the $x 960$ summer period. Their report, completed in late January I96I, was reproduced, and copies were transmitted in February to the Senate Subcommittee ${ }^{109}$ and made available to others, who requested them. ${ }^{110}$

At the end of the introduction to their report, the Committee of Consultants stated their general conclusion:

The central conclusion of the study is that the agency responses, although they are in general critical of the Code in many respects, do not disclose that substantial revisions in the Code are necessary or desirable, and do leave substantially unimpaired the arguments for its enactment into law.

${ }^{105}$ See Federal Administrative Procedure Hearings, supra note 19, at 105.

${ }^{108}$ Experience with the enactment of the Administrative Procedure Act of 1946 would belic any such expectation.

107. Amendment of one provision might require correlative amendment of another, which might well be overlooked.

${ }^{108}$ The Committee consisted of Leo A. Huard, Dean of the University of Santa Clara College of Law, Chairman; Rex A. Collings, Jr., of the University of California School of Law; and Winston M. Fick, of Claremont Men's College and Claremont Gradaute School.

${ }^{109}$ As to the Senate Subcommittee's interest in this report, see Federal Administrative Procedure Hearings, supra note 19, at 56-58, r05.

${ }^{110}$ Copies have been filed in the Law Library of Congress. For access to the comparatively small number of remaining copies, inquiry may be made of the Washington office of the American Bar Association, I120 Connecticut Ave., Washington 6, D.C. 
While this is their general conclusion, the report of the Committee of Consultants finds some of the detailed agency comment justified, and itself makes suggestions for revision of the Code text. A number of these our Committee on the Code has already determined to accept.

The next step should, I think, be hearings before the Senate Subcommittee, on the Code text, ${ }^{111}$ agency comment thereon, and the Consultants Committee report. Conferences with representatives of the agencies could also be useful, especially if the number were small enough to permit detailed consideration of the Code text. The Director of an Office of Administrative Procedure could, ideally, correlate agency views for such a conference. I doubt that the form of organization of the new Administrative Conference of the United States would lend itself to effective consultative procedure on the text of a statute of this scope.

I have said above that proposals of the Hoover Commission and its Task Force on Legal Services and Procedure are not properly to be attributed to the American Bar Association; and what I said applies to the Code. The Task Force drafted an "Administrative Code"112 that included in its first two titles ${ }^{113}$ a proposed revision of the Administrative Procedure Act of r946. The Hoover Commission transmitted the Task Force Administrative Code to the Congress, though without endorsement. ${ }^{114}$ The Task Force proposal was, of course, among the matters studied by the Association's Special Committee on Legal Services and Procedure; but our proposed Code, as anyone who compares the three documents must agree, differs more from the Administrative Code proposed by the Task Force than it does from the I946 Act.

Our own Code is to be judged on its merits. The reach of the Code is so wide, and its provisions so detailed, that full discussion would be impossible within the limits of this paper. I proceed to discuss illustratively' the reasons for major proposals.

\section{A. Public Information}

Section 3 of the I946 Act ${ }^{115}$ was intended to provide adequate public information with respect to the product of agency rulemaking and adjudication; but in practice agencies have on occasion justified restrictive information practices by reference to this very section (and to 5 U.S.C. $\S 22$ ). In 1956 , after long study and hearings

111 The Senate Subcommittee has held no hearings directed to the specific provisions of S.Io7o. The hearings of July and November 1959, Administrative Procedure Legislation Hearings, were on S. 2374 , see note 43 supra and related text; and on title I of S.600, see note 5I supra and related text. The hearings of November and December 1960, Federal Administrative Procedure Hearings, supra note 19, were held not to consider particular bills in detail, $i d$. at 2, but to consider a wide range of problems of administrative procedure, with incidental but not detailed consideration of particular bills.

112 TASR Force Report 359 et seq.

${ }^{113}$ Title I-"Definitions"; title II-"Procedure." The remaining titles were: III-“Office of Legal Services and Procedure"; IV-“"Administrative Court of the United States"; V-"Hearing Commissioners"; VI-"Appearance and Representation"; VII-"General Provisions."

114 E.g., Hoover CoMm'n Report 5I, 95.

${ }^{215} 60$ Stat. 238,5 U.S.C. $\$ 1002$ ( 1958 ). 
by its Special Subcommittee on Government Information, the House Committee on Government Operations reported:116

Clarification of statutes.-The Congress has a duty to clarify the chaotic and confusing situation existing with respect to title 5, United States Code, section 22, and title 5. United States Code, section I002. Action is required in order to spell out the intent of Congress and to insure a freeing rather than a freezing of information. It is believed that Congress intended to establish a full and complete flow of information from the Government to the people, but the fact remains that misinterpretation of congressional intent exists. A major effort is being made to develop specific legislative language concerning these two statutes. ...

The basic purpose of section 1002 of the Code, "Public Information," is to cure this misapprehension of the congressional intention.

In I957 and again in 1959, Senator Hennings introduced a bill to amend section 3 of the 1946 Act; ${ }^{117}$ the Hennings bill resembles generally section 1002 of our proposed Code, but with changes. Our Committee on the Code considered carefully the differences between the Hennings bill and ours, and determined that we should accept some (though not all) of the changes. I cannot go into detail here; but a memorandum of our conclusions in this regard was furnished in May I959 to the staff of the Senate Subcommittee on Administrative Practice and Procedure and the staff of the House Special Subcommittee on Government Information. 117a

Here, as elsewhere in the Code, proposals which may be opposed by some agencies are motivated by what we believe to be essentially in their own interest as well as in the public interest as I defined it at the beginning of this paper. It will, I think, be useful to refer again in this connection to the article by H.W.R. Wade, a member of the British Council on Tribunals, to which I have already referred for an account of that Council's activities during its first year. ${ }^{118}$ The House of Lords, in the Arlidge case, ${ }^{119}$ had upheld the general practice of refusing publication of reports to ministers by inspectors who had conducted local inquiries. The Franks Committee recommended that such inspectors' reports be disclosed. ${ }^{120}$ Mr. Wade writes: $:^{121}$

... But now at last the change has been made, the reports are made available, and we are glad to find the Chief Inspector of the Ministry of Housing and Local Government saying in print that the new practice has markedly improved public relations. . . .

${ }^{110}$ House Comm. on Government Operations, Availability of Information from Federal Departments and Agencies, H.R. Rep. No. 2947, 84th Cong., 2d Sess. 93 (1956). 5 U.S.C. $\$ 22$ was amended in 1958 to add: "This section does not authorize withholding information from the public or limiting the availability of records to the public." 72 Stat. 547 .

${ }^{112}$ S.21 48, 8 th Cong., Ist Sess. (1957), S.186, 86th Cong., Ist Sess. (1959).

${ }_{1172}$ On April 12, 196I, Senator Carroll, chairman of the Subcommittec on Administrative Practice and Procedure, introduced for himself and others S.1567, 87th Cong., Ist Sess., to amend $\$ 3$ of the 1946 Act. The new bill resembles in many respects, though in a few respects it differs from, $\$ 1002$ of the proposed Code with the changes we had determined to accept following our consideration of the Hennings bill."

${ }^{118}$ Wade, supra note 6 , and see note 69.

${ }^{129}$ Local Government Board v. Arlidge [1915] A.C. 120.

${ }^{120}$ CMND. No. 218, at 97.

121 Wade, stpra note 6 , at 33 . 


\section{B. Rulemaking}

I should mention first the change that the Code would effect in the definition of "rule" and "rulemaking." Section roor(c) reads:

(c) Agency Rule and Rulemaring.-_"Rule" means the whole or any part of eyery agency statement of general applicability and future effect implementing, interpreting, or declaring law or policy, or setting forth the procedure or practice requirements of any agency. "Rulemaking" means agency process for the formulation, amendment, or repeal of a rule.

Section 2(c) of the $1946 \mathrm{Act}^{122}$ includes in its definition statements of particular (as well as general) applicability (and future effect), and includes specifically the approval or prescription for the future (whether generally or in particular application) of "rates, wages, corporate or financial structures or reorganizations thereof, prices, facilities, appliances, services or allowances therefor or of valuations, costs, or accounting, or practices bearing upon any of the foregoing."

The basis for the definition in the 1946 Act is, I assume, that the matters it includes are legislative in nature. The rationale of the draftsmen of the Code is that we are dealing with a procedural statute; that in this context procedural requirements, not concepts of the nature of administrative action, are what count; and that where the procedure must be quasi-judicial, ${ }^{123}$ a procedural statute should define the action as adjudication. ${ }^{124}$

The instances in which rules (as defined by the Code) are required to be made on the record of a prescribed hearing are relatively few. I confine discussion here to procedures for participation in informal rulemaking by those who would be affected by the rules. The purpose is, as I have suggested earlier in more general application, not only fairness to those whose interests may be severely affected, but also assurance that the administrative action will be informed and considered.

The provisions of section 4 of the Administrative Procedure Act of $1946^{125}$ for public notice of proposed rulemaking and public participation in the rulemaking process are in effect limited to substantive rules, and even as to substantive rules are not applicable "in any situation in which the agency for good cause finds (and incorporates the finding and a brief statement of the reasons therefor in the rules issued) that notice and public procedure thereon are impracticable, unnecessary, or contrary to the public interest."

Under section 1003 of the Code, public notice and public participation would be required in the making of procedural and interpretative, as well as substantive, rules. The exceptions would be only for matters required to be kept secret in the protection

12260 Stat. 237,5 U.S.C. $\$ 100 r(c)(1958)$.

${ }^{12 a}$ See Morgan v. United States, 298 U.S. 468, 479-8I (I936).

12" Both the I946 Act and the Code in effect define "adjudication" as whatever final agency action is not "rulemaking." Administrative Procedure Act of 1946, $\$ 2(d), 60$ Stat. 237, 5 U.S.C. $\$$ roor(d) (1958); Code $\$$ roor (d).

${ }^{235} 60$ Stat. 239,5 U.S.C. $\$ 1003$ (1958). 
of the national security; rules relating to public property, loans, grants, benefits, or contracts to the extent that the agency finds that the delay or expense would be disproportionate to the public interest; and rules relating solely to internal management.

The requirements of the 1946 Act for public notice and public participation in informal rulemaking are, it seems clear, much too narrow, both in the interest of those affected and in the wider public interest in sound administrative action. To make sure, on the other hand, that the broader requirements of the Code do not hamper prompt and effective administration, the Code provides for "temporary or emergency rules,"126 which, under specified criteria, may be adopted without the prescribed notice and public participation but will have effect for not more than six months unless extended in accordance with the regular notice and participation requirements. This is, I believe, a sound solution.

Besides these major provisions, section 1003 of the Code contains a number of procedural improvements, including, for example, provisions that agencies must adopt and publish rules of procedure for rulemaking; must keep a rulemaking docket so that those affected may at all times be aware of what rulemaking is in process; and must deal effectively with petitions for the issuance, amendment, or repeal of rules. ${ }^{127}$ While these are of less consequence, they are still important in insuring the benefits of outside participation in the informal rulemaking process.

\section{Formal Adjudication}

I select for discussion two major features-the increased status the Code would confer on the hearing commissioners provided for by the Federal Administrative Practice Act, and the Code's extension of the separation-of-functions provisions of the 1946 Act.

\section{Hearing commissioners}

The Code provides that in every case in which a hearing commissioner presides (that is, in all but the rare cases where the agency itself or an agency member or a board specifically authorized by statute may preside), ${ }^{128}$ the hearing commissioner shall make an initial decision, which in the absence of an appeal to the agency or a review upon motion of the agency will become the decision of the agency; ${ }^{120}$ and it provides further that, upon agency review of the initial decision, a hearing commissioner's findings of evidentiary fact (as distinguished from ultimate conclusions of fact-and of course from questions of agency policy) shall not be set aside by the agency unless such findings are contrary to the weight of the evidence. ${ }^{130}$ Under section $8(a)$ of the $1946 \mathrm{Act},{ }^{131}$ in contrast, the agency may take for its own initial

${ }^{120} \$ \mathrm{IOO}_{0}(\mathrm{~d})$.

${ }^{127}$ While the 1946 Act provides for such petitions, there has been too wide experience that petitions when filed disappear from sight.

${ }^{128} \S 1006(\mathrm{a})$.

$120 \$ 1006(\mathrm{~b})(\mathrm{lo}), 1007(\mathrm{~b})$. Under $\$ 1003(\mathrm{~b})$, the requirement that a hearing commissioner make an initial decision is not applicable to formal rulemaking.

${ }_{130} \S 1007(c)$.

13160 Stat. 242,5 U.S.C. $\$ 1007$ (a) (1958). 
decision a case heard by a trial examiner and, even where it is reviewing an initial decision of a trial examiner, the agency may substitute its own decision (decisions of evidentiary fact included) for that of the examiner. ${ }^{132}$ The Code ${ }^{133}$ would also give to the hearing commissioner more control over the proceeding before him than hearing examiners in many agencies now have.

The increased status that the Code would thus confer on hearing commissioners would go far to improve responsible administrative adjudication, permitting the hearing officer to whom a case has been directly presented by evidence and argument to play his proper part in the final determination.

It is widely recognized that too much time of agency members is spent on adjudication, impeding the proper exercise of their other functions and causing in some agencies extreme delays in the adjudication process itself. One solution is for an agency to provide in effect for final adjudication by qualified hearing officers in run-of-the-mill cases, with the agency exercising discretionary power of review where more is involved than questions of fact and where the novelty or importance of the other questions involved makes final adjudication by the agency appropriate. ${ }^{\mathbf{1 3 4}}$ The high quality of hearing commissioners assured by title II of the Federal Administrative Practice Act, and the provisions of the Code that I have just discussed, conferring adequate powers on hearing commissioners, would contribute greatly to making such procedure practicable.

\section{Separation of functions}

I have mentioned above, ${ }^{135}$ though without discussion, the widespread interest in bills to curb ex parte influence on agency adjudication. Those bills deal with influence brought to bear on the agency from the outside. The problem of internal ex parte influence would be dealt with in the Code by its provisions requiring separation of functions in the process of agency decision.

The separation-of-functions provisions of the 1946 Act, section $5(\mathrm{c}),{ }^{188}$ are inapplicable "in any manner to the agency or any member or members of the body comprising the agency." The Code would extend its separation-of-functions provisions, section roo5(c), to the agency and agency members. ${ }^{137}$ The portion of section 1005 (c) applicable to agency members is as follows:

... Except upon notice and opportunity for all parties to be present or to the extent required for the disposition of ex parte matters as authorized by law, no such presiding or deciding officer or agency or member of an agency acting pursuant to sections 1006 and

${ }^{133}$ This is subject only to the fact that on judicial review the trial examiner's report may be taken into account by the reviewing court in determining the sufficiency of the evidence to support the agency's determination. Universal Camera Corp. v. NLRB, 340 U.S. 474, 492-97 (195r).

${ }^{133} \S 1006(b)$ and (c).

${ }^{134}$ See, e.g., Federal Administrative Procedure Hearings, supra note I9, at I00-0I; LaNdis, op. cit. supra note 48 , at 85 .

${ }^{186}$ See notes 42 and 43 supra and related text.

${ }^{130} 60$ Stat. 240,5 U.S.C. $\$ 1004$ (c) (1958).

${ }^{237}$ Under $\S 1003(b)$, the separation-of-functions provisions of $\S 1005$ (c) are not applicable to formal rulemaking. 
roo7 of this Act shall consult with any person or party on any issue of fact or law in the proceeding, except that, in analyzing and appraising the record for decision, any agency member may ( $\mathrm{r}$ ) consult with other members of the agency in cases in which the agency is making the decision, (2) have the aid and advice of one or more personal assistants, (3) have the assistance of other employees of the agency who have not participated in the proceeding in any manner, who are not engaged for the agency in any investigative functions in the same or any current factually related case and who are not engaged for the agency in any prosecutory functions.

The provision, it will be observed, permits agency members adequate assistance "in analyzing and appraising the record for decision," but it closes the door to influence within the agency, permissible under the I946 Act, on agency members who decide cases. Without such restriction, responsible adjudication, in which evidence and argument and counter-evidence and counter-argument of the parties can be brought to bear openly and effectively on the matters to be decided, is impossible.

Much is made, by those who support the process of what is called "institutional decision," of the expertness of agencies. Certainly agencies have, especially on their staffs, many experts. The question is how this expertness is to be used, in the public interest as I have suggested it should be defined, in the process of administrative adjudication. Certainly it can, and I think it should, be used openly on the record. To permit it to be used off the record, not merely in analyzing and appraising the record for decision but rather in derogation of or in substitution for or in addition to the record evidence, is a wholly different matter. One basic consideration here is that expert opinion or "knowledge," insulated against being critically reviewed and controverted, cannot be trusted to arrive always at the right result.

It is accepted doctrine that evidence not in the record must not be taken into account in the decision. ${ }^{138}$ It is accepted doctrine also that an agency may, in the decision process, use its expert knowledge and experience in evaluating and drawing conclusions from the evidence that is in the record. ${ }^{130}$ The line is not always easy to draw. ${ }^{140}$ That makes it all the more important that the statute call upon agencies to do their best in drawing the line.

\section{Judicial Review}

In New York, the availability of judicial review of administrative action, formal or informal, ${ }^{141}$ is the norm; and the view that administrative action should almost always be subject to the judgment of a reviewing court that the agency has stayed within the bounds of its authority, that its action within those bounds has conformed to procedural requirements, and that it has reached a rationally supportable conclusion, is a view not confined to lawyers outside the government. Thus when the

${ }^{138}$ United States v. Abilene \& Southern Ry. Co., 265 U.S. 274, 286.90 (1924).

${ }^{138}$ See ICC v. Louisville \& Nashville R.R., 227 U.S. 88, 98 (rgr3).

${ }^{100}$ See Benjamin 206 et seq., esp. 210.

${ }^{261}$ As to New York review of informal administrative action by a proceeding "in the nature of mandamus," and as to the few instances of action not subject to such review, see id. at 35 I et seq. 
New York Court of Appeals construed section 34 of the Insurance Law to exclude judicial review of matters other than those explicitly stated in the statute to be "subject to judicial review,"142 the succeeding Superintendent of Insurance himself obtained a curative amendment by the Legislature. ${ }^{143}$

The general availability of judicial review in New York has not impeded effective administration; nor (in view of the accepted limitations on the scope of judicial review, which tend to discourage resort to the courts) have the courts been overburdened with review proceedings.

The proposed Code is, I believe, wise in providing that every "final agency action" shall, "except as expressly precluded by Act of Congress hereafter enacted," be subject to judicial review. ${ }^{144}$ Reconsideration on the merits of the existing exemptions will require justification on clear grounds of policy if the exemption is to be continued ${ }^{\mathbf{1 4 5}}$ exemptions which cannot meet that test will not be continued by inertia or by the practical difficulty of piecemeal amendment of particular statutes.

General availability of judicial review does not, especially in the federal courts, mean that review will be obtained in every instance in which it is sought. There may still stand in the way a variety of doctrines, especially the doctrines of "standing to sue" and "ripeness for review."146

I may usefully refer at this point to a discussion of the proposed Code before the District of Columbia Bar Association three years ago, in which I had the pleasure of participating with Clark Byse. ${ }^{147}$ Mr. Byse said at one point that he thought the effect of the Code was to give agencies and the judiciary a "nudge here and a nudge there, ${ }^{, 148}$ and I accepted this as a happy characterization. ${ }^{149}$

This figure of speech of Mr. Byse's applies neatly to the Code's treatment of the doctrine of "standing to sue"-in Mr. Justice Frankfurter's words, a "complicated specialty of federal jurisdiction."150 The Code provision is ${ }^{151}$

Standing to Seer Review.-Any person adversely affected or aggrieved by any such reviewable agency action shall have standing to seek judicial review thereof, except where expressly precluded by Act of Congress hereafter enacted.

${ }^{\text {x*2 }}$ Matter of Guardian Life Ins. Co. v. Bohlinger, 308 N.Y. 174, 124 N.E.2d I Io (1954), reargument denied, 308 N.Y. 810, 125 N.E.2d 867 (1955).

${ }^{14}$ N.Y. Sess. Laws 1956 , ch. 932 , amending $\$ 34$ to read in part:

"Notwithstanding the specific enumerations of the right to judicial review in this chapter, any order, regulation or decision of the superintendent is declared to be subject to judicial review as permitted in a proceeding under article seventy-eight of the civil practice act. . . ."

${ }_{141} \$ 1009(a)$.

165 Where such grounds exist, the agency should have no difficulty in presenting them to the Congress.

${ }^{1 " s} \mathrm{See}$, as to the complexities of these doctrines, Kenneth Culp Davis, Administrative Law TrEATISE $\$ \S 21.01-22 . x 8$ (1958).

${ }^{147}$ The substance of this discussion is reported in Smalley, The Federal Administrative Procedure Act: Its Accomplishments and Proposals for Amendments, 5 FED. B. News I38 (1958).

${ }^{148}$ Id. at 139 .

${ }^{110} \mathrm{lbid}$. I did not agree with the implied answer to his further question, whether the cumulative effect of the nudges "was not a shove."

${ }_{150}$ United States ex rel. Chapman v. FPC, 345 U.S. 153, 156 (1953).

$101 \S 1009$ (b). 
This simple and direct statement ${ }^{152}$ would, I believe, convey to the courts an effective indication of congressional intent that, for example, they go further than they have done in finding "standing" wherever the one seeking review is adversely affected in fact by agency action, and that they be slow to deny "standing" on the ground that no "legal right" of the one seeking review has been infringed. I welcome support in this view from Robert Kramer, ${ }^{153}$ who (though he criticizes various provisions of the Code) finds that this provision would "clarify the ambiguity of the present language" of the 1946 Act, and seems "highly desirable."154 Of course no statutory provision, however explicit, could require the courts to find "standing" or "ripeness" where they do not find a "case" or "controversy," necessary to confer jurisdiction under article 3 , section 2, of the Constitution.

The doctrine of "ripeness for review" is not, I believe, capable of statutory formulation even in suggestive form; and the Code attempts none. The Code's suggestive treatment of "standing" may, however, suggest to the courts greater liberality also in finding "ripeness" than they have always shown.

Besides broadening the availability of judicial review, the Code makes a valuable contribution by providing for a review proceeding in the United States district court of appropriate jurisdiction, except where a particular statute provides for judicial review in a specified court. ${ }^{155}$ This section is useful also in providing that review proceedings may be brought against the agency, individuals who comprise the agency, or "any person representing the agency or acting on its behalf in the matter sought to be reviewed in the judicial district where the defendant resides or wherein the act or omission complained of occurred."156

One new provision of the Code authorizing judicial action has met opposition, in my view clearly mistaken. Section $1009(\mathrm{~g})$ provides in part: ${ }^{167}$

Procerdings in Excess of JURisdiction.-U U Uon a showing of irreparable injury, any Federal court of competent jurisdiction may enjoin at any time the conduct of any agency proceeding in which the proceeding itself or the action proposed to be taken therein is clearly beyond the constitutional or statutory jurisdiction or authority of the agency. If the court finds that any proceeding contesting the jurisdiction or authority of the agency is frivolous or brought for the purpose of delay, it shall assess against the petitioner in such proceeding costs and a reasonable sum for attorneys' fees (or an equivalent sum in lieu thereof) incurred by other parties, including the United States.

${ }^{162}$ Compare $\$ 10(a)$ of the 1946 Act, 60 Stat. 243,5 U.S.C. $\$ 1009$ (a) (1958):

"RIGHT OF REVIEW.-Any person suffering legal wrong because of any agency action, or adversely affected or aggrieved by such action within the meaning of any relevant statute, shall be entitled to judicial review thereof."

${ }_{263}$ Later Assistant Attorney General in charge of the Office of Legal Counsel.

${ }^{155}$ Kramer, The Place and Function of Judicial Review in the Administrative Process, 28 Fond. L. Rev. I, 35 (1959).

${ }_{165} \S 1009$ (c). Compare $\S 10(b)$ of the 1946 Act, 60 Stat. 243,5 U.S.C. $\S$ roog(b) (1958); and see Kramer, stupra note 154 , at $35-36$.

${ }^{156}$ See Smalley, supra note I47, at I4x; cf. Blackmar v. Guerre, 342 U.S. 512 (1952).

${ }^{157}$ See also a related provision of $\S 1005(a)$, authorizing like injunctive action with respect to investigations. 
This used to be the law, ${ }^{158}$ though without the safeguard provided by the second quoted sentence. The proceeding is, in essence, the familiar New York proceeding "in the nature of prohibition," "159 which (with its predecessor, the historic writ of prohibition) has been in effect for many years without disruption of the administrative process. Those who object to the Code provision fail, I believe, to recognize that an injunction would lie only if the proposed action were "clearly" beyond the agency's jurisdiction or authority. The cases in which that could be shown to the satisfaction of the court would be cases in which the remedy ought to be available to avoid the "irreparable injury" which the court must also find.

I mention, finally, two provisions regarding the scope of judicial review.

Section roog(f) (7) of the Code would substitute, in the review of determinations of fact in formal adjudication, a "clearly erroneous" test for the present test of "substantial evidence on the whole record." As to this, having myself expressed a differing view in the 1956 report of the Special Committee on Legal Services and Procedure, ${ }^{160}$ I confine myself to justifying the proposal as (in Byse's phrase) a "nudge" to the courts to apply the substantial evidence test to its fullest permissible extent. ${ }^{101}$

Section $\operatorname{roog}(f)$ of the Code provides also that the reviewing court

... shall determine all questions of law and interpret the statutory and constitutional provisions involved and shall apply such interpretation to the facts duly found or established.

This provision is intended, in part, to overrule the doctrine of Gray v. Powell ${ }^{162}$ and National Labor Relations Board v. Hearst Publications, Inc., ${ }^{163}$ which I have discussed elsewhere as "judicial deference to quasi-judicial statutory interpretation." "164 I must refer to that discussion here, quoting only my conclusion that the doctrine "accomplishes little of affirmative value that could not be accomplished by the established doctrine that courts, free to reach their own conclusions on statutory interpretation, will nevertheless give weight to an administrative interpretation," while

${ }^{158}$ Skinner \& Eddy Corp. v. United States, 249 U.S. 557, 562-63 (1919).

160 Benjamin 360 et seq.

${ }^{100}$ Special Comm. on Legal Services and Procedure, Report, 8r A.B.A. Rep. 49x, 529-30 (r956).

101 Similarly, the provision of $\S 1006(d)$ of the Code, requiring the application in formal adjudication, to the extent practicable, of the rules of evidence applicable in civil nonjury cases in the district courts (a provision as to which I also expressed differing views, id. at 528-29), might be justified as a "nudge" to the agencies to formulate the rules of evidence that they will apply in practice, instead of leaving their own evidence practices wholly at large. See BENJAMIN I78-8r. I should add that this evidence provision" of $\S$ roo6(d) is not applicable to formal rulemaking or to "cases of adjudication involving the approval or prescription for the future of rates, wages, corporate or financial structures or reorganizations thereof, prices, facilities, appliances, services, or allowances thereof, or valuations, costs, or accounting, or practices bearing upon any of the foregoing"; in such cases, "any reliable and probative evidence" is to be received.

${ }^{102} 3{ }_{4}$ U.S. 402 (r94r).

208322 U.S. III (I944).

10s Benjamin, Judicial Review of Administrative Adjudication: Some Recent Decisions of the New York Court of Appeals, $4^{8}$ Colum. L. Rev. I, $\mathrm{x}_{2}$ et seq. (I948). 
it involves the danger "that administrative tribunals, free to adopt any rationally supportable interpretation of the governing statute, will be freed of the ultimate legal controls which have been a useful, no less than a traditional, part of our system of administrative law."165

It had been thought by some, myself included, that section ro(e) of the $1946 \mathrm{Act}^{100}$ would be effective to overrule the doctrine. It did not have that effect; and I believe that this is the time to try, more explicitly, again.

\section{VI}

\section{Concluding Misceilany}

I repeat that the American Bar Association's legislative program is not advanced as sufficient in itself to solve all the problems of federal administrative procedure. To put this paper in perspective, I conclude here with disconnected comment on a few of the questions to which, in discussing that program, I have not had occasion to refer. These are largely matters of agency organization and procedure with which I would expect our proposed Office of Administrative Procedure, and in some instances the new Administrative Conference of the United States, to deal. In the following comment I refrain, generally, from suggesting solutions.

There is the question of combining in an agency legislative and adjudicatory functions. The basic argument for doing so is that administrative legislation and adjudication are part of a single process, where policy may first be developed in a series of adjudicatory proceedings and then, as it crystallizes, may be profitably generalized into rules. Doubt has been cast on this combination of functions by recently publicized instances of $e x$ parte influence on adjudication. Legislative activity, it is said, must be carried on not in isolation but in frequent consultation and informal contact with those subject to regulation. But the very questions that are later the subject of adjudication may thus have been discussed informally at an earlier time; and to draw the line against $e x$ parte influence at the point where actual adjudication begins is in such circumstances unrealistic.

There is a question whether agencies should not go further than they have done in determining policy by rulemaking as soon as that is practicable, rather than continuing, after that point of practicability is reached, the process of developing policy by adjudication. The advantage to those subject to regulation of knowing in advance the criteria according to which they will be regulated is obvious. The difficulty is in determining the point at which the formulation of rules is practicable.

There is, so far as I can see, no way in which agencies can be forced to crystallize policy in rules, even when it would clearly be practicable to do so. If an agency

${ }^{208}$ Id. at I4.

${ }^{100} 60$ Stat. 243,5 U.S.C. 1009 (e) (1958). 
wants to rely on a rule in support of its action, it must of course promulgate the rule; ${ }^{107}$ if it does not want that support, it cannot be forced to do so. Whether it should not in good conscience do so is another matter. If, for example, an agency has formulated instructions to its subordinate personnel how to deal with matters affecting those subject to regulation, I have difficulty in finding justification for concealing from those regulated the substance of what has been concluded by such instructions.

It has been suggested that, with the modern techniques of data-processing, many of the questions now dealt with in extended rulemaking or adjudicating proceedings could be more efficiently dealt with in that way. ${ }^{168}$ I would still ask who determines, and by what process he determines, what data are to be fed into the data-processing machine and what formula the machine is to apply to those data.

There have been undertaken in recent years a number of management surveys of agency activities. I would conclude, with the reference to Judge Prettyman with which I began, by saying that administrative regulation is more than management.

\section{ADDENDUM}

This article was substantially completed in early April. I note here, briefly, some of the developments since.

On April i3, the President issued an Executive Order ${ }^{109}$ establishing the Administrative Conference of the United States "to assist the President, the Congress and the administrative agencies and executive departments in improving existing administrative procedures." The Conference consists of a Council of eleven members named by the President, one of whom-Judge Prettyman-he has designated as Chairman of the Conference, and "a general membership from Federal executive departments and administrative agencies, the practicing bar, and other persons specially informed by knowledge and experience with respect to Federal administrative procedures." The composition of the general membership, not less than fifty in number, is to be determined by the Council; "at least a majority of the total membership shall be from Federal executive departments and administrative agencies." Research and staff assistance are to be furnished by the Office of Administrative Procedure in the Department of Justice, and the Director of that Office acts as Executive Secretary of the Conference. The Conference is required to make a final report to the President no later than December 3I, I962, "summarizing its activities, evaluating the need for further studies of administrative procedures, and suggesting appropriate means to be employed for this purpose in the future." Provision is made for studies by Conference committees, and for participation in the activities of the Conference by

\footnotetext{
${ }^{107}$ See Code $\S 1002(e)$, which provides in part:

"No rule . . . shall be relied upon or cited against any persons unless it has been duly published or made available to the public in accordance with this section."

${ }^{168}$ See Federal Administrative Procedure Hearings, supra note 19 , at 28.

${ }^{200}$ Exec. Order 10934, 26 Fed. Reg. 3233 (I96r).
} 
interested committees of the Congress. The Conference has already entered on its activities, from which much of value is to be expected. ${ }^{\mathbf{1 7 0}}$

On April 14, the Subcommittee on Administrative Practice and Procedure of the Senate Committee on the Judiciary issued a second report. ${ }^{171}$ I do not undertake here to summarize the report, but set forth in a footnote the report's own summary statement of its nine recommendations. ${ }^{172}$

Following the Subcommittee's recommendation "to increase the prestige and power of hearing examiners,"173 Senator Carroll, chairman of the Subcommittee, introduced on April $27^{174}$ S. 1734,87 th Cong., Ist Sess., to amend sections 7 and 8 of the Administrative Procedure Act of 1946, primarily to provide that in formal adjudication and formal rulemaking the officer who presides shall make an initial decision which, in the absence of review by the agency, shall become the decision of the agency, and to provide that review by the agency shall be only upon one or more of grounds specified in the bill. The Code of Federal Administrative Procedure proposed by the American Bar Association provides for the initial-decision procedure in formal adjudication, but not in formal rulemaking. ${ }^{175}$ I have expressed above $\mathrm{e}^{170}$ approval of the procedure of final adjudication by qualified hearing officers in runof-the-mill cases, with the agency exercising discretionary power of review where

${ }^{170}$ See, e.g., note Ig supra and related text.

${ }^{17 \pm}$ Subcomm. on Administrative Practice and Procedure of the Senate Comm. on the Judiciary, Administrative Practice and Procedure, S. REP. No. I68, 87th Cong,, Ist Sess. (1961) [hereinafter cited as S. REP. No. I68].

172 "I. The subcommittee recommends the enactment of a statute to give legislative ratification of the existing power of the President to promulgate an ethical code governing the conduct of Government employees and providing sanctions for the violation of that code." Id. at 3 .

"II. The subcommittee recommends the enactment of a statute containing both criminal and civil sanctions prohibiting improper ex parte communications." Id. at 4 .

"III. The subcommittee recommends that there be established in the White House an Office of Administration and Reorganization with adequate personnel and an adequate budget." Id. at 5 .

"IV. The subcommittee recommends that legislation should be enacted to increase the terms of regulatory agency members to uniform terms of ro years, together with an annual increment in salary and with strengthened provisions for pension rights." Id. at 6.

"V. The subcommittee recommends the enactment of legislation to increase the prestige and power of hearing examiners, and to adjust their compensation to a rate commensurate with such added stature of these officers." Id. at 7 .

"VI. The subcommittee recommends that every assistance should be given in making permanent an Administrative Procedure Conference, and that Congress should provide the Office of Administration and Reorganization with funds to provide a permanent secretariat for that Conference." $1 d$. at 9 .

"VII. The subcommittee recommends against the present enactment of any general revision of the Administrative Procedure Act." Id. at Io.

"VIII. The subcommittee recommends the enactment of legislation to protect consumers from delays by which utilities have been able to amass capital by filing unjustificd applications for rate increases." Id. at II.

"IX. The subcommittee recommends the enactment of legislation which will minimize the difficulties of obtaining speedy and convenient judicial review of agency decisions." Id. at I2.

${ }^{173}$ Id. at $7-9$.

${ }^{174}$ For himself, Senator Hart (the other majority member of the Subcommittee), and Scnator Long of Missouri.

${ }^{175}$ See note 129 supra and related text. Discussion of the application of the initial-decision procedure to formal rulemaking is complicated by the difference between the definition of "rulemaking" in the proposed Code and the definition in the Administrative Procedure Act of r946. See page 227 stupra.

${ }^{176}$ See note 134 supra and related text. 
the novelty or importance of the question involved makes final adjudication by the agency appropriate; and that approval was repeated in behalf of the American Bar Association in a hearing on S. 1734 held by the Subcommittee on May I8. The American Bar Association has not yet taken a position on the question whether the grounds for discretionary agency review should be specified by statute, as S. I734 would do, or should be left to definition by agency rule under specific rulemaking power granted by statute. ${ }^{177}$

In my view the recommendation of the Subcommittee report against present enactment of any general revision of the Administrative Procedure Act ${ }^{178}$ does not represent a final conclusion. When the report was written, there had been inadequate time for study of the report of the American Bar Association's Committee of Consultants $^{179}$ on our proposed Code, and the Code itself had not been the subject of detailed consideration at Subcommittee hearings. ${ }^{180}$ The hearing of May I8 on S. $1734^{181}$ gave opportunity for illustrating the advantages of general over piecemeal revision, and illustrated also the merits of some of the specific provisions of our proposed Code. My expectation is that with further detailed hearings of this kind and further study of the report of the Committee of Consultants, the Subcommittee will conclude that general revision in line with our proposed Code is desirable.

Finally, it appears to me that the provisions of our proposed Code with respect to judicial review ${ }^{182}$ encompass all that the Subcommittee proposes in its recommendation on that subject. ${ }^{183}$

${ }^{177}$ The latter approach is taken by reorganization plans transmitted by the President to the Congress in April and May, which apply to much besides formal adjudication.

${ }^{178}$ S. REP. No. I68, at IO-II.

${ }^{170}$ See notes 108 and 109 supra and related text.

${ }^{180}$ See note III supra.

${ }^{181}$ The transcript of this hearing has not yet been published.

${ }^{182}$ See pages $23 \mathrm{x}-34$ stipra.

${ }^{188}$ S. REP. No. I68, at I2. 